\title{
EFFECTIVENESS OF VARIOUS CONCENTRATIONS OF LEMONGRASS LEAF EXTRACT LOTION (Cymbopogon nardus) AS REPELLENT OF AEDES AEGYPTI MOSQUITOES
}

\author{
Firda Ro'in 1), Agus Subagiyo ${ }^{2)}$, Arif Widyanto ${ }^{3)}$, Nur 'Aini 4) \\ 1) 2) 3)Environmental Health Department of, Health Polytechnic Ministry of Health Semarang, \\ Jl.Raya Baturraden KM 12 Purwokerto, Indonesia
}

\begin{abstract}
Effectiveness Of Various Concentrations Of Lemongrass Leaf Extract Lotion (Cymbopogon nardus) As Repellent Of Aedes aegypti Mosquitoes. Dengue Hemorrhagic Fever (DHF) is a disease caused by dengue virus which is transmitted through the bite of the Aedes aegypti mosquito. Vector control efforts that are popular in the community are using chemical insecticides. The use of insecticides can cause mosquito resistance and cause poisoning in humans. Then effective controls need to be developed to avoid these impacts. Safe control of health and environmentally friendly is to use natural repellent derived from plants, one of which is lemongrass leaf (Cymbopogon nardus). The purpose of this study is to know the effectiveness of various concentrations of lemongrass leaf extract lotion (Cymbopogon nardus) as repellent of Aedes aegypti mosquitoes. This type of research is an experimental laboratory with the research design of The Posttest - Only Controlled Group Design. The research method by hand control and treatment is presented in a cage containing 25 Aedes aegypti mosquitoes for 6 hours with repetition 10 times each hour. The results showed that a concentration of $20 \%$ had an average protective capacity of $82.8 \%$, a concentration of $40 \%$ had an average protective capacity of $95.0 \%$, an concentration of $80 \%$ had an average protective capacity of $98.1 \%$ and lotion repellent from chemicals with the brand "X" has an average protection capacity of $88.6 \%$. The results of the Kruskal Wallis analysis proved significant with $\mathrm{p}=0.003<\alpha(0.05)$, so there were significant differences in the protective power. The conclusion of the study was that the lemongrass leaf extract lotion was effectively used as a repellent of Aedes aegypti mosquitoes at a concentration of $40 \%$ and $80 \%$ because the protective power value> $90 \%$ even though it had been used for 6 hours.
\end{abstract}

Keywords: Repellent, Aedes aegypti, Lemongrass Leaf Extract Lotion

\section{Introduction}

Diseases that are transmitted through vectors are still endemic diseases that can cause outbreaks or extraordinary events and have an impact on the economic loss of society, so it is necessary to control the spread of vectors (Permenkes RI Number 50 of 2017).

Dengue Hemorrhagic Fever is a disease caused by the dengue virus which is transmitted through the bite of the Aedes aegypti mosquito. The transmission of dengue disease basically occurs due to the presence of dengue virus sufferers or carriers, the Aedes aegypti mosquito as the vector and the community as the target (Sukana, 1993).

Dengue Hemorrhagic Fever (DHF) is a public health problem in Indonesia where the number of sufferers is increasing and its spread is increasingly widespread, dengue is an infectious disease that generally attacks children aged less than 15 years and can also affect people. adults (Widoyono, 2005).

The use of chemical mosquito repellents in the form of lotions, creams, or the like that can protect the body from mosquito bites can actually endanger health. Almost all mosquito repellent lotions circulating in Indonesia contain the active ingredient DEET (Diethyl toluamide) which is a

Synthetic insecticides from these chemicals have a high risk of danger, especially to health, so there is a need for alternative dengue vector control efforts that use natural, environmentally friendly and lower risk materials, namely making natural repellents using plants that contain active substances that can kill. mosquitoes and plants that are widely found in the community, one of the plants that has the potential as a natural mosquito repellent is lemongrass leaves.

Lemongrass contains essential oil components with components of geraniol $(20-40 \%)$, citronellal (25-50\%), and citronellol (10-15\%) which cause aroma, so it can be used as a mosquito repellent (Agusta, 2000). In addition to being used as a repellent, lemongrass oil can also be used in the cosmetic field, namely as the main ingredient in soaps, skin lotions, and perfumes (Essential oils, 2010). 
The ash from the leaves and stalks contains $49 \%$ silica which is the cause of desiccation (the continuous discharge of body fluids) on the skin of insects so that the insects will die from drying out. Citronellol and geraniol are active ingredients that are not liked and are highly avoided by insects, including mosquitoes, so the use of these materials is very useful as mosquito repellents. (Agus Kardinan. 2006, p. 27).

Based on previous research (Alifatul Mahampang, 2018) states that a concentration of $10 \%$ protects $95 \%$ (1 fish) for 15 minutes.

Based on this, the authors wrote the title: "The Effectiveness of Various Concentrations of Lemongrass Leaf Extract (Cymbopogon nardus) Lotion as Repellent for Aedes aegypti Mosquitoes".

\section{Materials and Methods}

a. How to Make Lemongrass Leaf Extract

1) Tool

Shekker, Rotary evaporator, Kabhinet dryer, Blender, Erlenmeyer, Funnel, Tray, Knife

2) Materials

Citronella leaves as much as 1000 grams, Ethanol 96\%, Filter paper, Plastic bags

3) Sample Preparation

Prepare samples / ingredients (citronellaleaves), Wash thoroughly, Thinly slice, Place on a tray and dry using room temperature until the leaves dry completely.

4) Sample Preparation

a) Samples or ingredients that have dried in the blender into powder

b) Put in the Erlenmeyer

c) Add solvents in a 1:3 ratio (1 sample section and 3 solvent parts)

d) Put in a glass jar and cover with aluminum foil so that the sample is not in direct contact with light

e) Shake with a shekker for 72 hours, so that it dissolves in $96 \%$ ethanol

f) Strain with filter paper

g) Put the filtrate in the pumpkin evaporator

h) Connect the evaporator from the power source

i) Set tool temperature $40^{\circ} \mathrm{C}$

j) Let samples and solvents separate

k) Solvent results obtained with extracts

1) The finished extract is put in a special container

5) Formula

Extract rendemen $=\frac{\text { extract weight }}{\text { simplisia weight }} \times 100 \%$

Description : a. Rendemen extract : the number of extracts produced after the extraction process $(\%)$

b. Bobot extract : the weight of the extract resulting from the extraction process

c. Simplisia weight: clove leaf weight used to make eextract

6) Calculation

- Known:

-. Extract rendemen $=10 \%$

- Simplisia weight $=1000$ gr

- Asked: Extract weight $(\mathrm{X})=\ldots$. gr ?

- Jawab :

Extract rendemen $=\frac{\text { extract weight }}{\text { simplisia weight }} \times 100 \%$ $10=\frac{X}{10}$

$\mathrm{X}=100 \mathrm{gr}$

So, the weight of the extract to be produced is 100 grams.

b. How to Make Various Concentrations of Lemongrass Leaf Extract Lotion

Thick citronella leafextract, TEA 4\%, Stearic acid $15 \%$, Cetil alcohol $2 \%$, Glycerin 15\%, Nipagin $0.12 \%$, Nipasol $0.12 \%$, Aquades $50 \mathrm{ml}$, Pot place lotion 3 pieces.

The initial process of making lotion extract is:

1) Melted oil phases i.e. stearic acid, cetil alcohol, and nipasol are inserted into a cup of porcelain A, stirred until homogeneous.

2) Melt the water phases of glycerin, TEA, nipagin, and aquadest in a cup of porcelain B stirred until it forms an emulsion corpus.

3) Next prepare a hot mortar.

4) After the oil phase and water phase in each porcelain cup are melted, insert the oil phase and water phase simultaneously into the mortar hot and stir constantly.

5) Add citronella leaf extract according to the required concentration of $20 \%$ into a hot mortar stirred constantly until homogeneous until the lotion period forms or until the temperature on the mortar drops.

6) Put in a pot / container of preparations.

7) Do the same for the manufacture of citronella leaf extract lotion $40 \%$ and $80 \%$.

8) Lotion lemongrass leaf extract ready to use

\section{Repellent Test Against Aedes Aegypti} Mosquitoes 


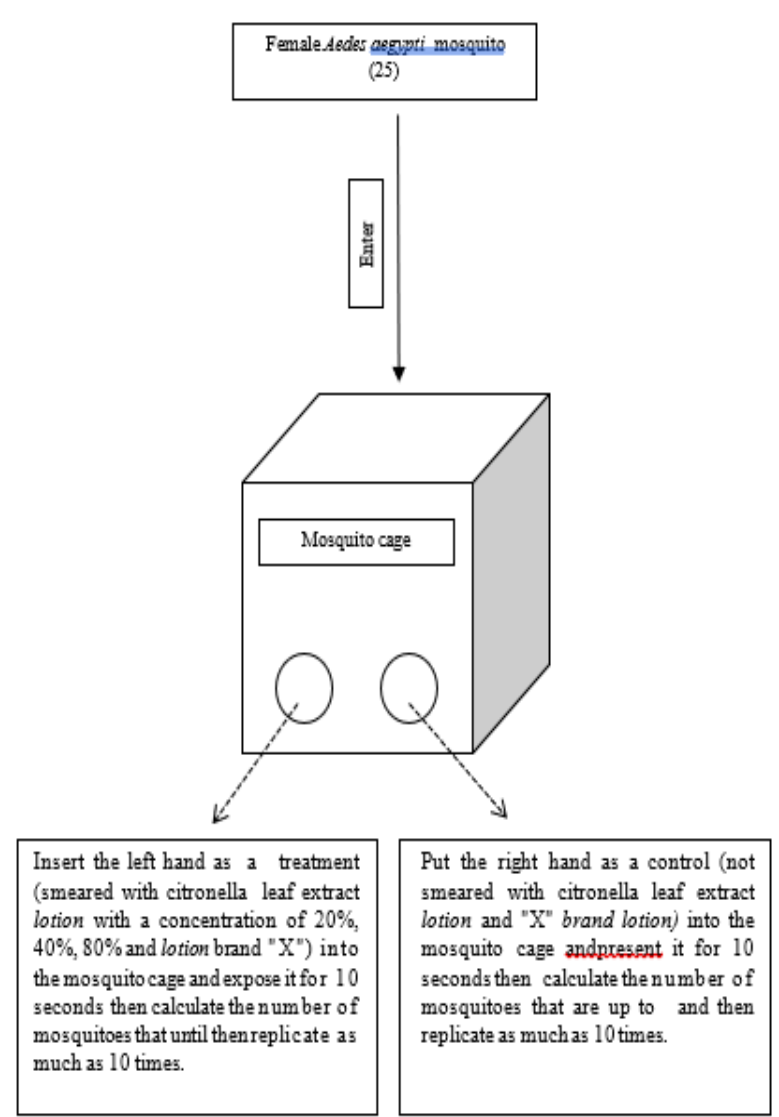

Research Scheme Images

The efficacy of the repellent tested is determined based on the protection power calculated by the formula:

Power Protection (DP) : $\frac{(\mathrm{K}-\mathrm{R})}{\mathrm{K}} \times 100 \%$

Description:

$\mathrm{K}=$ The number of ups and downs in the control hand

$\mathrm{R}=$ The number of up to the hands of treatment

Repellent is considered effective if until the 6th hour Power Protection is still $>90 \%$. (Pesticide Commission of the Ministry of Agriculture, 1995, p.2).

\section{Data Analysis}

The type of research used is a laboratory experiment with the research design Of The Posttest - Only Control Group Design. Dependent variables used in the form of the number of female Aedes aegypti mosquitoes that perpetuate the probandus hand,independent variables in theform of various concentrations of lemongrass leaf extract lotion. Statistical analysis that Kruskal Wallis used with Mann Withney's advanced test.

\section{Results And Discussions}

a. Air Temperature Conditions

The results of air temperature measurement with thermometer measuring instruments at the research site (Laboratory Loka Litbangkes Pangandaran) are as follows:

Table 4.1 Air Temperature Measurement Results

\begin{tabular}{|c|c|c|c|}
\hline $\begin{array}{l}\text { Types of } \\
\text { Repellent }\end{array}$ & Concentration & $\begin{array}{c}\text { Initial } \\
\text { Temperature } \\
\left({ }^{\circ} \mathbf{C}\right)\end{array}$ & $\begin{array}{c}\text { Temperat } \\
\text { ure After } \\
6 \text { Hours } \\
\left({ }^{\circ} \mathrm{C}\right)\end{array}$ \\
\hline lemongra & $20 \%$ & 26 & 26,5 \\
\hline $\begin{array}{l}\text { ss Leaf } \\
\text { Extract }\end{array}$ & $40 \%$ & 26 & 26,5 \\
\hline Lotion & $80 \%$ & 26 & 26,5 \\
\hline $\begin{array}{l}\text { Lotion } \\
\text { "X" }\end{array}$ & - & 26 & 26,5 \\
\hline \multicolumn{2}{|c|}{ Average } & 26 & 26,5 \\
\hline
\end{tabular}
temperature at the study site indicated that the initial air temperature was $26^{\circ} \mathrm{C}$ and the air temperatureafter 6 hours was $26.5^{\circ} \mathrm{C} .1$

\section{b. Air Humidity Conditions}

The results of air humidity measurement with a higrometer measuring instrument at the research site (Laboratory Loka Litbangkes Pangandaran) are as follows:

Table 4.2 Air Humidity Measurement Results

\begin{tabular}{cccc}
\hline $\begin{array}{c}\text { Types of } \\
\text { Repellent }\end{array}$ & Concentration & $\begin{array}{c}\text { Initial } \\
\text { Humidity } \\
(\mathbf{\%})\end{array}$ & $\begin{array}{c}\text { Humidity } \\
\text { After 6 } \\
\text { Hours } \\
(\%)\end{array}$ \\
\hline lemongrass & $20 \%$ & 73 & 72 \\
Leaf & $40 \%$ & 73 & 72 \\
Extract & $80 \%$ & 73 & 72 \\
Lotion & - & 73 & 72 \\
Lotion "X" & - & 73 & 72 \\
\hline \multicolumn{2}{c}{ Average } & \\
\hline
\end{tabular}

Based on Table 4.2 The average air humidity at the study site showed that air humidity was $73 \%$ and humidity after 6 hours was $72 \%$.

c. Light Intensity

The results of light intensity measurement with Luxmeter measuring instrument at the research site (Laboratory Loka Litbangkes Pangandaran) are as follows:

$\underline{\text { Table 4.3 Light Intensity Measurement Results }}$

\begin{tabular}{cccc}
\hline $\begin{array}{c}\text { Types of } \\
\text { Repellent }\end{array}$ & Concentration & $\begin{array}{c}\text { Initial } \\
\text { Light } \\
\text { Intensity } \\
\text { (Lux) }\end{array}$ & $\begin{array}{c}\text { Light } \\
\text { Intensity } \\
\text { After 6 } \\
\text { Hours } \\
\text { (Lux) }\end{array}$ \\
\hline $\begin{array}{c}\text { lemongrass } \\
\text { Leaf }\end{array}$ & $20 \%$ & 105,9 & 237,4 \\
Extract & $40 \%$ & 105,9 & 237,4 \\
Lotion & $80 \%$ & 105,9 & 237,4 \\
Lotion "X" & - & 105,9 & 237,4 \\
\multicolumn{2}{c}{ Rata-rata } & 105,9 & 237,4 \\
\hline
\end{tabular}

Based on Table 4.3 Light intensity measurements are placed on the research desk. The average initial light intensity at the research site was 105.9 Lux and the light intensity after 6 hours was 237.4 Lux.. 
d. Number of Aedes aegypti Mosquitoes That Are Caught In The Hands of Probandus

Repellent is applied to the hands of probandus treatment as much as 3 grams, then the hand is put in a cage. Mosquitoes that get into the hands of probandus are observed and calculated in number. The number of Aedes aegypti mosquitoes that are on the hands of probandus smeared with repellent lotion of lemongrass leaf extract with a concentration of $20 \%, 40 \%, 80 \%$ and lotion brand " $\mathrm{X}$ " with replication of 10 times can be seen in the following table:

Table 4.4 Number of Aedes Aegypti Yang Until The Handsof Probandus

Based on Table 4.4 $\mathrm{R}$ ata the average number of Aedes aegypti mosquitoes that reached the probandus hand for 6 hours indicated that the results tend to vary by $20 \%$ concentration amounting to $0.3 \%$ (30 heads)), concentrationof $40 \%$ amounted to $0.08 \%$ ( 8 heads), concentration of $80 \%$ amounted to $0.03 \%$ ( 3 heads)) and lotion brand " $\mathrm{X}$ " amounted to $0.27 \%$ (27 heads)).

e. Power Protection Lotion Lemongrass Leaf Extract and Lotion Brand "X"

Protection power can be calculated by using Aedes aegypti mosquito data that reached the probandus hand after smeared with lemongrass leaf extract lotion with a concentration of $20 \%, 40 \%$, $80 \%$ and brand lotion " $\mathrm{X}$ " with replication 10 times during 6 hours test time, can be calculated using the following formula:

Power Protection $=\frac{K-R}{K} \times 100 \%$

Description:

$\mathrm{K}=$ the number of mosquitoes that get under control

$\mathrm{R}=$ the number of mosquitoes that are infected with the treatment

The protection power of Aedes aegypti mosquitoes after being calculated using the formula is as follows:

Table 4.5 Power Protection Lotion Lemongrass Leaf Extract and Lotion Brand "X"

\begin{tabular}{|c|c|c|c|c|c|c|c|}
\hline \multirow{2}{*}{$\begin{array}{c}\text { Concentration } \\
\text { of } \\
\text { LemongrassLeaf } \\
\text { Extract Lotion } \\
(\%) \text { and Lotion } \\
\text { "X" }\end{array}$} & \multirow{2}{*}{ Replikasi } & \multicolumn{6}{|c|}{ Jam Ke- } \\
\hline & & 1 & 2 & 3 & 4 & 5 & 6 \\
\hline $20 \%$ & $1 \mathrm{~s} / \mathrm{d} 10$ & 100 & 64,2 & 75 & 75 & 86,6 & 85,7 \\
\hline $40 \%$ & $1 \mathrm{~s} / \mathrm{d} 10$ & 94,1 & 100 & 100 & 88,2 & 100 & 87,5 \\
\hline $80 \%$ & $1 \mathrm{~s} / \mathrm{d} 10$ & 100 & 100 & 95,2 & 100 & 100 & 94,1 \\
\hline Lotion "X" & $1 \mathrm{~s} / \mathrm{d} 10$ & 100 & 87,5 & 90,4 & 84,6 & 100 & 78,9 \\
\hline
\end{tabular}

Based on Table 4.5 Power proteksi protection lotion citronella leaf extract and lotion brand "X" against mosquitoes Aedes aegypti on probandus hand after lotion smeared with citronella leaf extract as shown that:

1) Protection power at the highest concentration of $20 \%$ is $100 \%$ at the 1 st hour while the lowest is $64.2 \%$ at the 2 nd hour, the average protection power for 6 hours is $82.8 \%$.

2) Protection power at the highest concentration of $40 \%$ is $100 \%$ at the 2nd, 3rd and 5th hours while the lowest is $88.2 \%$ at the 4 th hour, the average protection power for 6 hours is $95.0 \%$.

3) Protection power at the highest concentration of $80 \%$ is $100 \%$ at the 1 st, 2nd, 4th and 5th hours while the lowest is $94.1 \%$ at the 6th hour, the average protection power for 6 hours is $98.1 \%$.

\begin{tabular}{|c|c|c|c|c|c|c|c|c|c|}
\hline $\begin{array}{l}\text { Concentr } \\
\text { ation of } \\
\text { Lemongr }\end{array}$ & & & & Cloc & To & & & & \\
\hline $\begin{array}{l}\text { ) and } \\
\text { Lotion } \\
\text { "X" }\end{array}$ & & 1 & 2 & 3 & 4 & 5 & 6 & & \\
\hline $20 \%$ & $1 \mathrm{~s} / \mathrm{d} 10$ & 0 & $\begin{array}{l}0, \\
5\end{array}$ & $\begin{array}{l}0, \\
4\end{array}$ & $\begin{array}{c}0, \\
4\end{array}$ & $\begin{array}{l}0, \\
2\end{array}$ & $\begin{array}{l}0, \\
2\end{array}$ & 1,7 & 0,3 \\
\hline $40 \%$ & $1 \mathrm{~s} / \mathrm{d} 10$ & $\begin{array}{c}0, \\
1\end{array}$ & 0 & 0 & $\begin{array}{l}0, \\
2\end{array}$ & 0 & $\begin{array}{l}0, \\
2\end{array}$ & 0,5 & $\begin{array}{c}0,0 \\
8\end{array}$ \\
\hline $80 \%$ & $1 \mathrm{~s} / \mathrm{d} 10$ & 0 & 0 & $\begin{array}{c}0, \\
1\end{array}$ & 0 & 0 & $\begin{array}{c}0, \\
1\end{array}$ & 0,2 & $\begin{array}{c}0,0 \\
3\end{array}$ \\
\hline $\begin{array}{l}\text { Lotion } \\
\text { "X" }\end{array}$ & $1 \mathrm{~s} / \mathrm{d} 10$ & 0 & $\begin{array}{l}0, \\
2\end{array}$ & $\begin{array}{l}0, \\
2\end{array}$ & $\begin{array}{l}0, \\
4\end{array}$ & 0 & $\begin{array}{l}0, \\
8\end{array}$ & 1,6 & $\begin{array}{c}0,2 \\
7\end{array}$ \\
\hline
\end{tabular}

The highest protection power on " $\mathrm{X}$ " brand lotions is $100 \%$ at the 1 st and 5th hours while the lowest is $78.9 \%$ at the 6 th hour, the average protection power for 6 hours is $88.6 \%$.

Protection power in each concentration of lemongrass leaf extract lotion and lotion brand "X" can be selectedat the chart as follows: :

Picture 4.1 Power Protection Graph

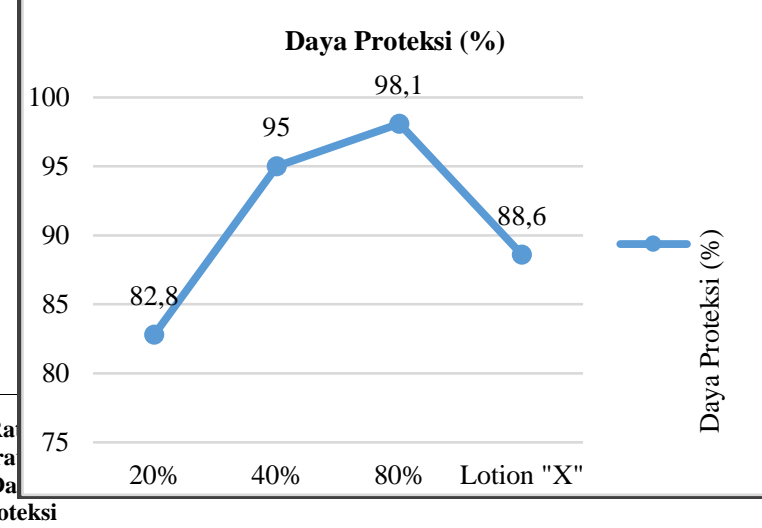

\%) Based on Figure 4.1 The protection power graph can be known that the higher the concentration of citronella leaf extract lotion then has a higher ${ }_{95}$ protection power (the Aedes aegypti mosquitoes that ${ }_{98}$ are on the hands are reduced) and when compared to the brand lotion " $\mathrm{X}$ " the result of lower protection ${ }^{88}$ power (more Aedes aegypti mosquitoes that get on the hands) from concentrations of $40 \%$ and $80 \%$. 
f. Statistical Test Results

Statistical test is used to find out the protection power of citronella leaf extract lotion against Aedes aegypti mosquitoes that are on the hands of probandus. Statistical test used is to use Kruskal Wallis (non parametric) as a test alternative to analyze the data because one of the requirements of the Anova test is not met is the data is not distributednormally, further to find out the difference in the protection power of citronella leaf extract lotion and mosquito repellent lotion from chemicals with the brand "X" against mosquitoes Aedes aegypti that reached between concentrations used Mann Whitney test.

1) Kruskal Wallis Test

Kruskal Wallis test is used with the aim to find out the difference in the protection power of citronella leaf extract lotion and mosquito repellent lotion from chemicals with the brand " $\mathrm{X}$ " against Aedes aegypti mosquitoes that are caught on the hands of probandus with various concentrations.

Table 4.6 Kruskal Wallis Test

\begin{tabular}{ll}
\hline & Daya Proteksi \\
\hline Chi-Square & 13,642 \\
df & 3
\end{tabular}

$$
\text { Asymp. Sig. } \quad 0,003
$$

Based on Table 4.6 daya proteksi terhadap Kruskal Wallis test results from the data as shown obtained $p=0$ results, $003<\alpha 0.05$ then the data is categorized as significant or distributed normally, so $\mathrm{Ha}$ accepted means there is a difference in protection power against Aedes aegypti mosquitoes that reached the probandus hand after smeared with lemongrass leaf extract lotion (Cymbopogon nardus)) concentration of $20 \%, 40 \%, 80 \%$ and mosquito repellent lotion from chemicals with the brand " $\mathrm{X}$ ". Then followed by the Whitney Mann test..

\section{2) Whitney Mann Test}

The Mann Whitney test was used with the aim of finding out the difference in the protection power of citronella leaf extract lotion and mosquito repellent lotion from chemicals under the brand " $\mathrm{X}$ " against Aedes aegypti mosquitoes that are caught in the hands of probandus with various concentrations. The full Whitney Mann test results are in table 4. 7 as follows:

Table 4.7 Whitney Mann Test

\begin{tabular}{|c|c|c|c|}
\hline $\mathrm{t}$ & $\begin{array}{l}\text { Asymp } \\
\mathrm{n}\end{array}$ & lification & Description \\
\hline $0 \%$ & 0,018 & $*$ & difference. \\
\hline $0 \%$ & 0,002 & $*$ & difference. \\
\hline otion X & 0,469 & $\mathrm{~ns}$ & ence \\
\hline
\end{tabular}

\begin{tabular}{lll}
$0 \%$ & $0,103 \mathrm{~ns}$ & ence \\
otion $\mathrm{X}$ & $0,066 \mathrm{~ns}$ & ence \\
otion $\mathrm{X}$ & $0,009 *$ & difference. \\
\hline \multicolumn{2}{c}{ Description : } & $*=$ significant if the $\mathrm{p}<0,05$ \\
& $\mathrm{~ns}=$ non-significant if $\mathrm{p}>0,05$
\end{tabular}

Based on Table 4.7 Mann Whitney test results as shown that it can be known if $p<0.05$ then there is a difference and $\mathrm{p}>0.05$ then there is no difference. Concentration $20 \%$ with $40 \% \mathrm{p}=0.018$ $<0.05$ which means there is a difference in protection power against mosquitoes that are in the hands of probandus. Concentration $20 \%$ with $80 \% \mathrm{p}=0.002$ $<0.05$ which means there is a difference in protection power against mosquitoes that are in the hands of probandus. Concentration $20 \%$ with lotion brand " $\mathrm{X}$ " $\mathrm{p}=0.469>0.05$ which means there is no difference in protection power against mosquitoes that are in the hands of probandus. Concentration $40 \%$ with $80 \% \mathrm{p}=0.103>0.05$ which means there is no difference in protection power against mosquitoes that are in the hands of probandus. Concentration of $40 \%$ with lotion brand "X" $\mathrm{p}=$ $0.0066>0.05$ which means there is no difference in protection power against mosquitoes that get into the hands of probandus. Concentration $80 \%$ with lotion brand " $\mathrm{X} " \mathrm{p}=0.009<0.05$ which means there is a difference in protection power against mosquitoes that are in the hands of probandus.

Table 4.8 Mann Whitney's Advanced Test

\begin{tabular}{|c|c|c|c|c|c|c|}
\hline $\begin{array}{c}\text { Treatm } \\
\text { ent }\end{array}$ & $80 \%$ & $40 \%$ & $20 \%$ & $\begin{array}{r}\text { Loti } \\
\text { on } \\
\text { X }\end{array}$ & $\begin{array}{l}\text { Mean } \\
\text { Rank }\end{array}$ & $\begin{array}{c}\text { Nota } \\
\text { tio } \\
\text { n }\end{array}$ \\
\hline $80 \%$ & - & & & & 12,75 & $\mathrm{a}$ \\
\hline $40 \%$ & $\underset{*}{0,009}$ & - & & & 16,05 & b \\
\hline $20 \%$ & $\begin{array}{c}0,066 \\
\text { ns }\end{array}$ & $\underset{\mathrm{ns}}{0,103}$ & - & & 24,15 & $a b$ \\
\hline $\begin{array}{c}\text { Lotion } \\
\text { X }\end{array}$ & $\begin{array}{c}0,469 \\
\text { ns }\end{array}$ & $\begin{array}{c}0,002 \\
*\end{array}$ & $\underset{*}{0,018}$ & - & 29,05 & ac \\
\hline
\end{tabular}

Whitney's advanced test as shown can be found that the higher the concentration, the more significant the result. Judging from the Mean Rank table, it is known that the highest protection power (the number of mosquitoes that get up to a little) is the concentration of $80 \%$ with an average of 12.75 followed by $40 \%$ with an average of 16.05 then $20 \%$ with an average of 24.15 and lotion brand " $\mathrm{X}$ " with an average of 29.05 as the lowest protection power (the number of mosquitoes that are up to a lot). 


\section{Conclusions And Suggestions}

a. Infers

Based on the data of the research entitled "

Effectiveness of Various Concentrations of Lotions Lemongrass Leaf Extract (Cymbopogon nardus) As Repellent Mosquito Aedes aegypti"can be concluded as follows:

1) The average number of Aedes aegypti mosquitoes that get on the hands that have been smeared with lemongrass leaf extract lotion (Cymbopogon nardus) is at a concentration of $20 \%$ amounting to $0.3 \%$ (30 heads), concentration $40.08 \%$ (8 heads), $80 \%$ consetration amounted to $0.03 \%$ (3 heads) and mosquito repellent lotion from chemicals under the brand " $\mathrm{X}$ " was $0.27 \%$ (27 heads).

2) The result of the analysis of protection power against Aedes aegypti mosquitoes that reached the hands se has proteksi been smeared with lemongrass leaf extract lotion (Cymbopogon nardus) at each concentration is a concentration of $20 \%$ has protection power $(82.8 \%)$, konr $40 \%$ have proteksi protection power $(95.0 \%)$, concentration $80 \%$ has protection power (98.1\%), and anti-mosquito lotion from chemicals with the brand " $\mathrm{X}$ " has power up to $(88.6 \%)$. It can be noted that the higher the concentration of lotions citronella leaf extract then has a higher protection power (Aedes aegypti mosquitoes that are on the hands are reduced) and when compared to the brand lotion "X" the result of protection power is lower (more Aedes aegypti mosquitoes are up on the hands) than concentrations of $40 \%$ and $80 \%$.

3) The results of kruskal wallis test showed the value of $p=0.003<\alpha \quad 0.05$, meaning there is a difference in protection power against the number of mosquitoes that reached the probandus hand after smeared with lemongrass leaf extract lotion (Cymbopogon nardus) at concentrations of $20 \%, 40 \%$ and $80 \%$ and anti-mosquito lotion from chemicals under the brand "X".

4) The results of the analysis of the effectiveness of protection power as a repellent after smeared with various concentrations of lemongrass leaf extract lotion and brand lotion "X" against Aedes aegypti mosquitoes on probandus hands showed the result that at an average concentration of $20 \%$ protection power of $82.8 \%$ for 6 hours, it is said to be ineffective. Concentration of $40 \%$ average protection power of $95.0 \%$ for 6 hours, it is said to be effective. Concentration of $80 \%$ average protection power of $98.1 \%$ for 6 hours, it is said to be effective. Lotion brand " $\mathrm{X}$ " average protection power of $88.6 \%$ for 6 hours, then it is said to be ineffective. From these results the most effective concentration is used as repellent, namely at concentrations of $40 \%$ and $80 \%$ can be proven from the value of stable protection power even though it has been used for 6 hours because of the value of protection against mosquito bites (above) $>90 \%$.

b. Advice

Based on the study entitled " Effectiveness of Various Concentrations of Lotions Lemongrass Leaf Extract (Cymbopogon nardus) As Repellent Mosquito Aedes aegypti" suggestions that can be submitted by researchers are as follows:

1)For The Community

People as consumers to be able to consider alternative uses of natural ingredients such as citronella leaves in efforts to control mosquito vectors.

2)For the Government

For the Government to be able to provide information and input in decision making to the government to the public in order to plan a program of control and eradication of vectors of DBD disease in order to use natural repellents namely lemongrass leaf extract lotion (Cymbopogon nardus)to reduce the impact of environmental pollution caused by the use of insecticide synthesis or chemical.

3)For Agencies

For health agencies can work with research institutes and agriculture departments to develop the results of this research as a natural mosquito control that can be recommended to the public.

4) Share Almamater

For Almamater can be used as one of the guidelines for community service in applying natural repellent in a village so that the community can benefit from the results of research.

5)For Other Researchers

a) There needs to be further research by combining other materials that can strengthen the protection power of

b) Analysis of the influence of host factors (skin color, skin tone, blood type)

c) Further research needs to be done on the active ingredients contained in lemongrass leaves along with the characteristics of these substances to be developed into mosquito repellent lotions.

d) It is necessary to conduct research on lemongrass leaf extract lotion using different extraction methods, for example by socletasi or perlocation or infusia methods.

e) It is necessary to conduct similar research on natural repellents using other types of plants, for example with basil leaf extract. 


\section{Refferences}

Boesri, Hasan, et al. 2015. Repelent Test (Reject Power) Of Some Extracts Plants Against Mosquito Bites Aedes aegypti Vector Dengue Hemorrhagic Fever. Vectora Vol. 7 No. 2, October 2015:79-84.

Budi Imansyah. 2008. Lemongrass Extract, Natural MosquitoRepellent. Bandung: AKL Kutamaya.

Cahyono, Tri. 2019. Thesis Writing Guidelines. Purwokerto : Ministry of Health Ri Polytechnic Health Department of Environmental Health Purwokerto.

Ministry of Health RI. 1999. Indonesia Healthy 2010, Jakarta : Ministry of Health RI.

Kardinan, Agus. 2006. Mosquito Repellent and Exterminator Plant. Tangerang : Agromedia Pustaka.

Ministry of Health, Directorate General of P2P (2018). Dengue Fever Situation in Indonesia in $2017 .$.

Mahmudah, Alifatul. 2018. Effectiveness of Citronella Extract (Cymbopogon nardus Lemongrass)Against Mosquito ProtectionPower. East Kalimantan: Muhammadiyah University of East Kalimantan.
Manurung, Rofirma. 2015. Effect of Citronella Juice Resistance (Cymbopogon nardus) Against Aedes aegypti Mosquito Bites. Medan: University of North Sumatra.

Puspita, Mega. 2009. Study of Effectiveness of Various Concentrations of Citronella Extract (Cymbopogon nardus)In Hand and Body Lotion As Aedes aegypti Mosquito Repellent in Banjarnegara. Purwokerto: Department of Environmental Health Poltekkes Kemenkes Semarang.

Setyaningsih, Dwi., et al. 2013. Application of CitronellaOil (Citronella Oil)And Geraniol In The Manufacture of Mosquito Repellent Skin Lotion. Penolak Nyamuk. Journal of Agricultural Industrial Engineering IPB.. Vol. 17(3),97-10.

Zulaikha, Guide. 2018. Effectiveness of Various Concentrations of Clove Leaf Extract (Syzygium aromaticum L) As Repellent Against The Power of Aedes Aegypti Mosquitoes in Lokalitbang P2B2 Ciamis. Purwokerto: Department of Health Lingkungan Poltekkes Kemenkes Semarang. 